\title{
Agrobacterium-mediated Genetic Transformation in Cucumber (var. Shital) as Influenced by Explant, Inoculation Time and Co-cultivation Period
}

\author{
S.M. Faisal ${ }^{1, *}$, M.S. Haque ${ }^{2}$, K.M.Nasiruddin ${ }^{2}$ \\ ${ }^{1}$ SSO, Horticulture Division, BARI, Regional Agricultural Research Station, Bangladesh \\ ${ }^{2}$ Department of Biotechnology, Faculty of Agriculture, BAU, Bangladesh
}

Copyright $(\underset{0}{2015}$ Horizon Research Publishing All rights reserved.

\begin{abstract}
To study genetic transformation for abiotic stress resistance in cucumber (var. Shital), leaf, nodal and internodal calli were subjected to Agrobacterium tumefaciens mediated transformation using LBA4404 strain containing CIPK sense gene. Transformation ability was examined by histochemical assay of GUS reporter gene in survived calli. Conspicuous GUS positive (blue colour) region were detected in callus tissue. There were 3 factors in this investigation. Factor A consisted of three types of explants viz. leaf, nodal and internodal callus, factor B consisted of two durations of inoculation time viz. 3 and $5 \mathrm{~min}$ and factor C consisted of two co-cultivation periods viz. 24 and 48 hours. The highest GUS positive transgenic callus obtained from leaf explants (3.30) and internodal explants gave the lowest number (1.79) of GUS positive transformants. Inoculation time is an important factor in transformation experiment mediated by $A$. tumefaciens. Transformation ability was increased with increase of inoculation time. Percentage of survived callus was higher $(53.68 \%)$ when the calli were immersed for $5 \mathrm{~min}$ in bacterial suspension. Both number and percentage of GUS positive callus were higher (3.17 and $52.87 \%$, respectively) when they were kept in bacterial suspension for higher time $(5 \mathrm{~min})$ and lower $(2.15$ and $35.88 \%$, respectively) when calli were soaked in bacterial suspension for minimum time (3 $\mathrm{min})$.
\end{abstract}

Keywords Cucumber, Genetic Transformation, Abiotic Stress

\section{Introduction}

Cucumber (Cucumis sativus L.) $(2 \mathrm{n}=14)$, a member of the family Cucurbitaceae, is one of the oldest vegetable crop supposed to be originate in India, between the Bay of Bengal and the Himalayas (Peirce, 1987) [14]. Cucumis sativus L. is a cucumber species which has commercial importance (Nonnecki, 1989) [13].
The total area and production of cucumber in Bangladesh during 2003 - 04 were 13925 ha and $25215 \mathrm{mt}$, respectively (BBS, 2005) [2]. The production has increased upto 32000 mt during the year 2006-'07 (BBS, 2008) [1]. The data indicates that total production has increased during the last few years with increased demand of cucumber. However, average yields of cucumber during 2002-'03, 2003-'04 and 2004-'05 were $4.45,4.45$ and $4.37 \mathrm{mt} / \mathrm{ha}$, respectively (BBS, 2006) [3] which indicate that the yield has declined slightly. Yield of cucumber is very low in our country compared to leading cucumber producing countries like China (12.24 t/ha), former USSR (7.57 t/ha), Japan (44.23 t/ha), USA (11.06 t/ha), Turkey (16.07 t/ha), Netherlands (192.50 t/ha), Spain (30.00 t/ha) (Nonnecki, 1989) [13]. Abiotic stresses include drought, salinity, extreme temperatures, chemical toxicity and oxidative stress are serious threats to agriculture and the natural states of environment (Wang et al., 2003) [17]. Without these, the population of our country is increasing day by day but the land is decreasing. Therefore, we need to utilize the lands which are not under cultivation at present, such as, coastal zone which have high saline properties. That's why we need millions of healthy cucumber seedlings in a short period of time.

In crop improvement, genetic transformation offers the ability to introduce new characters into a plant cultivar without altering its existing traits (Gardner, 1993) [8]. In all transformation experiments, specific reporter gene and one or more selectable marker gene are required to be introduced into the plant cell prior to the integration of gene (s) of interest. In this case, GUS-A ( $\beta$-glucoronidase) gene and neomycin phosphotransferase II termed as npt II (kanamycin resistant) gene have been used as reporter and selectable marker gene respectively. This reporter gene can be recognized in plant tissue with the help of selectable agents, confirming transformation of the plant tissue (through histochemical GUS assay). So, in this way, one can understand that the plant tissue subjected for transformation has really been transformed or not (Gardner, 1993) [8]. 
The use of genetic transformation may allow the production of abiotic stress resistant plants in a significantly shorter period of time than using conventional breeding, especially if several traits are introduced at the same time. The geographic spread of cucumber production may contribute to food, nutrition security and poverty alleviation in Bangladesh.

From the above background information it was revealed that tissue culture and genetic transformation of cucumber depend on several factors. So the present investigation was conducted to see the effect of explant, inoculation time and co-cultivation period on genetic transformation of cucumber

\section{Materials}

\section{Plant material}

Leaf, nodal and internodal calli of variety Shital were used in present investigation.

\section{Genetic transformation material}

Agrobacterium strain, plasmid and gene

Genetically engineered $A$. tumefaciens strain LBA4404 was used for infection in the pre-cultured explants. The strain is being maintained at the Biotechnology lab. under Bangladesh Agricultural University. This strain contains plasmid $\mathrm{pB} 1121$ of $14 \mathrm{kDa}$ (binary vector). This binary vector contains following genes within the right border (RB) and left border (LB) region of the construct-

i. The uidA gene (Jefferson, 1986) [9] encoding GUS ( $\beta$-glucuronidase), driven by CaMV promoter and NOS terminator. This reporter gene can be used to assess the efficiency of transformation.

ii. The $n p t$ II gene encoding neomycin phosphotransferase II (npt II) conferring kanamycin resistance, driven by NOS promoter and NOS terminator.

iii. The CIPK sense gene encoding calcineurin B-like protein conferring abiotic stress tolerance.

\section{Calcineurin B -like proteins (CIPK)}

Calcineurin $(\mathrm{Cn})$ is a unique $\mathrm{Ca}^{2+}$ dependent serine/threonine protein phosphatase (PP2B) of cytosol, which plays an important role in the coupling of $\mathrm{Ca}^{2+}$ signals to stress responses. Using degenerate primers from the conserved domains and by library screening a full-length cDNA (CIPK, 972 bp) was isolated from pea (accession no: AY883569). Plants respond to adverse environments by initiation a series of signaling processes that often involves diverse protein kinases, including calcineurin B-like protein interacting protein kinases (CIPKs). Putative CIPK genes $\left(\mathrm{O}_{\mathrm{s}} \mathrm{CIPK} 01-\mathrm{O}_{\mathrm{s}}\right.$ CIPK30) survived for their transcriptional responses to various abiotic stresses, like drought, salinity, cold, polyethylene glycol and abscisic acid treatment. To prove that some of these stress-responsive CIPK genes are potentially useful for stress-tolerance improvement, three CIPK genes (CIPK 03, CIPK 12, CIPK 15) were over expressed in Japonica rice. Transgenic plants over expressing the transgenes CIPK 03, CIPK 12, CIPK 15 showed significantly improved tolerance to cold, drought and salt stress, respectively. Under cold and drought stresses, CIPK 03, CIPK 12, over expressing transgenic plants accumulated significantly higher content of proline and soluble sugars. and putative proline synthetase and transporter genes had significantly higher expression level in the transgenic plants, against different stresses (Mahajan and Tuteja, 2005) [10].

\section{Methods}

Treatments: There were 3 factors in this experiment. Factor A consisted of three types of callus, factor B consisted of two inoculation times and factor $\mathrm{C}$ consisted of two co-cultivation periods.

A. Explants: Leaf, nodal and Internodal callus

B. Infection time: 3 and 5 minutes

C. Co-cultivation period: 24 and 48 hours

Total no. of treatments were $12(3 \times 2 \times 2)$. Each treatment consisted of 4 vials and replicated three times.

Design: Factorial in Completely Randomized Design (CRD)

\section{Media used}

Media used in the present study were as follows.

\section{A. For callus induction}

For induction and maintenance of callus, MS (Murashige and Skoog, 1962) [11] medium supplemented with different concentrations and combinations of BAP and NAA were used.

\section{B. For Agrobacterium culture}

Two types of culture media, namely, YMB (Yeast Extract Mannitol Broth) medium and LB (Luria Broth) medium were used with kanamycin as antibiotic to grow the strain of genetically engineered Agrobacterium tumefaciens. YMB medium was used for Agrobacterium maintenance and LB medium was used as Agrobacterium working culture medium for transformation work.

\section{For co-cultivation}

MS media without growth hormones were used for co-cultivation.

\section{For washing explants after co-cultivation}

Cefotaxime $(200 \mathrm{mg} / \mathrm{l})$ was used for washing the explants after co-cultivation.

\section{E. For Post-cultivation and regeneration}

MS media supplemented with $2 \mathrm{mg} / 1 \mathrm{BAP}, 1 \mathrm{mg} / \mathrm{l} \mathrm{NAA}$ and $100 \mathrm{mg} / \mathrm{l}$ cefotaxime were used for this purpose.

\section{F. For selection and regeneration}

Low selection medium: MS media supplemented with 2 
mg/l BAP, $1 \mathrm{mg} / \mathrm{l}$ NAA, $20 \mathrm{mg} / \mathrm{l} \mathrm{kanamycin} \mathrm{and} 100 \mathrm{mg} / \mathrm{l}$ cefotaxime were used.

High selection medium: MS media supplemented with 2 $\mathrm{mg} / \mathrm{l} \mathrm{BAP}, 1 \mathrm{mg} / \mathrm{l} \mathrm{NAA}, 30 \mathrm{mg} / \mathrm{l} \mathrm{kanamycin} \mathrm{and} 100 \mathrm{mg} / \mathrm{l}$ cefotaxime were used.

\section{Preparation of Culture Media}

\section{Preparation of MS medium}

The MS media used in this investigation were fortified with different concentrations and combinations of required auxin and cytokinin. They were added in the medium before the adjustment of $\mathrm{P}^{\mathrm{H}}$ of the solution.

\section{Preparation of Agrobacterium culture medium}

YMB medium was used for the maintenance of Agrobacterium strain LBA4404. The composition (Begam, 2007) [4] of the medium given below-

$\begin{array}{ll}\text { Mannitol } & 1.0 \% \\ \text { Yeast extract } & 0.04 \% \\ \mathrm{MgSO}_{4} .7 \mathrm{H}_{2} \mathrm{O} & 0.02 \% \\ \mathrm{NaCl} & 0.01 \% \\ \mathrm{KH}_{2} \mathrm{PO}_{4} & 0.05 \%\end{array}$

The $\mathrm{P}^{\mathrm{H}}$ was adjusted to 7.0-7.2 before adding agar at $1.5 \%$. After autoclaving the medium was cooled to $50-55^{\circ} \mathrm{C}$ and kanamycin was added at a rate of $0.05 \mathrm{mg} / \mathrm{l}$ and separated in petridishes.

\section{Preparation of LB (Luria Broth) medium}

To prepare one liter $(1000 \mathrm{ml})$ of LB medium, the following steps were followed-15.5 g of LB (Luria Broth) powder was taken into a 2-liter beaker on a magnetic stirrer.

i. $\quad 400-500 \mathrm{ml}$ of distilled water was poured in the beaker to dissolve the powder

ii. After dissolution the medium was transferred to a 1 liter measuring cylinder or volumetric flask and volume was made up to the mark with distilled water.

iii. Then the $\mathrm{p}^{\mathrm{H}}$ of the medium was adjusted to 7.0-7.2 with $0.1 \mathrm{~N} \mathrm{NaOH}$

iv. The medium was transferred back to stirred beaker to allow full mixing.

v. Batched (25-50 ml) of medium was transferred to clean $250 \mathrm{ml}$ conical flasks and plugged with non-absorbent cotton wool. The tops were covered with aluminum foil.

\section{Preparation of GUS assay solution}

The GUS straining solution is composed of the following chemicals.

\begin{tabular}{cc}
\hline Components & Amount $/ 10 \mathrm{ml}$ \\
\hline X-gluc (solvent: DMSO) & $8.89 \mathrm{mg}$ \\
Chloramphenicol & $200 \mu \mathrm{l}$. \\
$\mathrm{NaH}_{2} \mathrm{PO}_{4}$ & $119.8 \mathrm{mg}$ \\
Triton X $(10 \%)$ & $100 \mu \mathrm{l}$ \\
Methanol & $2 \mathrm{ml}$ \\
$\mathrm{P}^{\mathrm{H}}$ was adjusted at $7.0-8.0$ by adding $\mathrm{P}^{\mathrm{H}}-10$ buffer solution
\end{tabular}

For the preparation of $10 \mathrm{ml}$ GUS straining solution, the following steps were followed-
- All necessary glasswares were autoclaved.

- $\quad$ The $8.89 \mathrm{mg}$ X-gluc was weighted.

- Few drops of DMSO (Dimethyl Sulphoxide) were taken in a beaker and X-gluc was added.

- Gently shaken until all the X-gluc was dissolve.

- $200 \mu \mathrm{l}$ of chloramphenicol was added into the beaker.

- $10 \%$ titron $\mathrm{X}$ was prepared. Then $100 \mu \mathrm{l}$ Titron $\mathrm{X}$ from this solution was added to the $\mathrm{X}$-gluc solution.

- $2 \mathrm{ml}$ methanol was added to the solution and gently mixed and $\mathrm{P}^{\mathrm{H}}$ was adjusted to 7.15 by adding $\mathrm{P}^{\mathrm{H}}-10$ buffer solution.

\section{Sterilization Techniques}

\section{Sterilization of culture media}

The glasswares with medium were sterilized under 1.09 $\mathrm{kg} / \mathrm{cm}^{2}$ pressure at $121^{\circ} \mathrm{C}$ for $25 \mathrm{~min}$.

\section{Sterilization of glasswares and instruments}

Beakers, test tubes, conical flasks, pipettes, metallic instruments like forceps, scalpels, and inoculation loop, micropipette tips, eppendorf tubes, needles, spatulas were wrapped with aluminium foil, vials were capped with plastic cap and then sterilized in an autoclave at a temperature of $121^{\circ} \mathrm{C}$ for 30 minutes at $1.16 \mathrm{~kg} / \mathrm{cm}^{2}$ pressure.

\section{Culture techniques}

\section{i. Explant culture}

Explants (Leaf, node and internodal calli) were produced in present experiment from the shoots of cucumber seeds (variety Shital). Explants were separately placed horizontally on each vial and gently pressed into the surface of the sterilized culture medium supplemented with various concentrations and combinations of BAP $(0,1$ and $2 \mathrm{mg} / \mathrm{l})$ and NAA (1, 2 and $3 \mathrm{mg} / \mathrm{l})$. The culture vials containing explants were placed under dark in growth room with controlled temperature $\left(25 \pm 1^{0} \mathrm{C}\right)$. The vials were checked daily to note the response and the development of contamination if any.

\section{ii. Agrobacterium culture}

For maintenance the strain, one single colony from previously maintained Agrobacterium stocks was streaked onto freshly prepared petridish containing YMB medium having kanamycin. The petridish was sealed with parafilm and kept at room temperature for at least 48 hours. This was then kept at $4^{0} \mathrm{C}$ to check over growth. Such culture of Agrobacterium strain was thus ready to use for liquid culture. The cultures were subcultured regularly at each week in freshly prepared media to maintain the stock. For infection single colony of $A$. tumefaciens was picked and inoculated in a conical flask containing liquid LB medium with $50 \mathrm{mg} / 1$ kanamycin. The culture was allowed to grow at $28^{\circ} \mathrm{C}$ to get optimum growth of Agrobacterium for infection and co-cultivation of explants (calli). 


\section{iii. Infection}

The Agrobacterium grown in liquid LB medium was used for infection. Prior to this, optical density (OD) of the bacterial suspension was determined at $600 \mathrm{~nm}\left(\mathrm{OD}_{600}=\right.$ $0.60)$ with the help of a spectrophotometer. Following the determination of density, to pre-culture explants (calli) were dipped into bacterial suspension for 3 and $5 \mathrm{~min}$, respectively, before transferring them to co-cultivation medium.

\section{iv. Co-cultivation}

Following infection, the explants were co-cultured on co-cultivation medium. Prior to transfer of all explants (callus) to co-cultivation medium they were blotted with sterile tissue papers for a short period to remove excess bacterial suspension. All the explants were maintained in co-cultivation medium for 24 and 48 hours, respectively. Co-cultured explants were placed under fluorescent illumination with $16 / 8$ hours light/dark cycle at $\left(25 \pm 2^{\circ} \mathrm{C}\right)$. The intensity of light was maintained at 1800 lux (approximately). The culture vials were checked daily to observe any contamination and the behaviors of the explants.

\section{v. Washing and post-cultivation}

After co-cultivation for required periods, the infected explants were washed twice with sterile $\mathrm{ddH}_{2} \mathrm{O}$ and once with sterile $\mathrm{ddH}_{2} \mathrm{O}$ containing $200 \mathrm{mg} / \mathrm{l}$ cefotaxime. Then the explants were transferred onto post-cultivation medium containing $100 \mathrm{mg} / \mathrm{l}$ cefotaxime.

\section{vi. Transfer to selection medium}

Following one week of post-cultivation, the explants were transferred onto low selection MS medium supplemented with $2 \mathrm{mg} / \mathrm{l} \mathrm{BAP}+1 \mathrm{mg} / \mathrm{l} \mathrm{NAA}+20 \mathrm{mg} / \mathrm{l} \mathrm{kanamycin}+100$ $\mathrm{mg} / \mathrm{l}$ cefotaxime and also onto high selection MS medium fortified with $2 \mathrm{mg} / \mathrm{l} \mathrm{BAP}+1 \mathrm{mg} / \mathrm{l} \mathrm{NAA}+30 \mathrm{mg} / \mathrm{l}$ kanamycin $+100 \mathrm{mg} / \mathrm{l}$ cefotaxime.

vii. GUS ( $\beta$-Glucuronidase) histochemical assay

From each batch of calli following each transformation experiment, randomly selected survived calli were examined for GUS histochemical assay. For this test survived calli were immersed in X-gluc (5-bromo-4-chloro-3-indoly-1glucuronide) solution and were incubated at $37^{\circ} \mathrm{C}$ for overnight. A characteristic blue color would be the expression of GUS ( $\beta$-Glucuronidase) gene in the plant tissue. Proper control for GUS histochemical assay was done with the explants having no Agrobacterium infection. After X-gluc treatment explants were transferred to $70 \%$ alcohol for degreening. Following degreening explants were observed under stereomicroscope (Begam, 2007) [4].

viii. Transfer of the selected materials to regeneration medium

After ten days, the survived calli were transferred to regeneration medium consisting of MS medium supplemented with $1 \mathrm{mg} / \mathrm{l} \mathrm{NAA}+2 \mathrm{mg} / \mathrm{l} \mathrm{BAP}+20 \mathrm{mg} / 1$ kanamycine $+100 \mathrm{mg} / \mathrm{l}$ cefotaxime for regeneration.

\section{Data Recording}

To investigate the effects of different treatments and responses of different varieties to callus induction subsequent inoculation and regeneration, data were collected from the different parameters as given below.

\section{a) Number of survived callus}

The number of callus that is survived in each vial was recorded. The percentage of survived callus was calculated on the basis of the number of callus survived and the total number of callus tested with antibiotics.

b) $\underline{\text { Per cent of survived callus }}=\frac{\text { No. of survived callus }}{\text { Total no. of cultured callus }} \times 100$

c) Number of callus positive for GUS assay

The number of callus giving positive response to GUS histochemical assay was recorded.

\section{d) Percentage of callus positive for GUS (Percent GUS expression) assay}

The percentage of GUS positive calli were calculated on the basis of the number of calli assayed for GUS and the total number of calli positive for GUS.

\section{Results and Discussion}

\section{Effect of explant (callus)}

Influence of explants was found significant in all the parameters studied (Table 1). Among the explants leaf callus showed the best performance over nodal and internodal callus. The highest number (12.75) leaf callus was survived in co-cultivation medium followed by nodal callus (12.10) and the lowest number (10.95) was found in internodal callus. Regarding percentage of survived callus, leaf explants also showed the best performance $(53.11 \%)$ and the lowest survival percentage was found in internodal explants (45.60\%). In an investigation of Agrobacterium mediated genetic transformation of potato Begum (2005) [5] found that both number and percentage of survived calli per pertridish were higher (4.55 and $25.01 \%$, respectively) in leaf calli than internodal calli $(2.33$ and $11.16 \%$, respectively).

The highest GUS positive transgenic callus was obtained from leaf explants (3.30) and the internodal explants gave the lowest number (1.79) of GUS positive transformants. In case of percentage of GUS positive callus leaf explants gave the highest percentage (55.04\%). Nishibayashi et al. (1996) [12] reported that very young leaves of more than 50 percent plantlets when treated with $\mathrm{x}$-gluc displayed strong GUS expression. Rajagopalan and Perl-Treves (2005) [15] obtained the highest $(75 \%)$ GUS positive callus from cotyledon explants in cucumber. From above findings it was revealed that transformation ability may differ from explant to explant. 
Table 1. Main effect of explant on number and percentage of survived callus and GUS histochemical assay

\begin{tabular}{ccccc}
\hline Explant & $\begin{array}{c}\text { Number of } \\
\text { survived } \\
\text { callus }\end{array}$ & $\begin{array}{c}\text { \% of } \\
\text { survived } \\
\text { callus }\end{array}$ & $\begin{array}{c}\text { Number of } \\
\text { GUS + ve } \\
\text { callus }\end{array}$ & $\begin{array}{c}\text { \% of } \\
\text { GUS }+ \\
\text { ve } \\
\text { callus }\end{array}$ \\
\hline Leaf callus & $12.75 \mathrm{a}$ & $53.11 \mathrm{a}$ & $3.30 \mathrm{a}$ & $55.04 \mathrm{a}$ \\
$\begin{array}{c}\text { Nodal callus } \\
\text { Internodal } \\
\text { callus }\end{array}$ & $12.10 \mathrm{a}$ & $50.40 \mathrm{a}$ & $2.88 \mathrm{a}$ & $48.12 \mathrm{a}$ \\
\hline
\end{tabular}

Means in a column followed by uncommon letter (s) varied significantly at $5 \%$ level of significance

Table 2. Main effect of inoculation time and co-cultivation period on number and percentage of survived callus and GUS histochemical assay

\begin{tabular}{ccccc}
\hline Treatments & $\begin{array}{c}\text { Number of } \\
\text { survived } \\
\text { callus }\end{array}$ & $\begin{array}{c}\% \text { of } \\
\text { survived } \\
\text { callus }\end{array}$ & $\begin{array}{c}\text { Number of } \\
\text { GUS + ve } \\
\text { callus }\end{array}$ & $\begin{array}{c}\% \text { of } \\
\text { GUS }+ \\
\text { ve } \\
\text { callus }\end{array}$ \\
\hline \multicolumn{5}{c}{ Inoculation time } \\
\hline 3 mins. & 10.97 & 45.72 & 2.15 & 35.88 \\
5 mins. & 12.88 & 53.68 & 3.17 & 52.87 \\
\hline \multicolumn{6}{c}{ Co-cultivation period } \\
\hline $\begin{array}{c}\text { L } 4 \text { hrs } \\
\text { Level of } \\
\text { significance }\end{array}$ & 11.40 & 47.53 & 2.42 & 40.39 \\
\hline
\end{tabular}

$* *=$ Significance at $1 \%$ level

\section{Effect of inoculation time}

Inoculation time is an important factor in transformation experiment mediated by A.tumefaciens. The Agrobacterium mediated transformation system is historically the first successful plant transformation system, marking the breakthrough in plant genetic engineering in 1983. The breakthrough in gene manipulation in plants came by characterizing and exploiting plasmids carried by the bacterial plant pathogens. These provide natural gene transfer, gene expression and selection systems. In recent times, A. tumefaciens used as nature's most effective plant genetic engineer (Chawla, 2002) [6]. In present investigation, three types of callus were immeresed for 3 and $5 \mathrm{~min}$, respectively in Agrobacterium suspension to see the effect of inoculation time regarding transformation ability. Following immersion the calli were blotted and placed on co-cultivation medium. From Table 2, it was revealed that both inoculation times had highly significant influence on different parameters studied. Transformation ability was increased with increase of inoculation time. Percentage of survived calli were higher $(53.68 \%)$ when the calli were immersed for $5 \mathrm{~min}$ in bacterial suspension. Both number and percentage of GUS positive calli were higher (3.17 and $52.87 \%$, respectively) when callus were kept in bacterial suspension for higher time (5 min) and were lower (2.15 and $35.88 \%$, respectively) when they were soaked in bacterial suspension for minimum time (3 min). Rajagopalan and Perl-Treves (2005) [15] reported that they found maximum GUS expression $(93 \%)$ when calli were immersed either for 60 min or $120 \mathrm{~min}$ in bacterial suspension. They also mentioned that although GUS expression events increased with inoculation time but survival rate and regeneration capacity were dramatically reduced. So they selected $10 \mathrm{~min}$ as recommended inoculation time. From these findings it was understood that inoculation time play a vital role in Agrobacterium mediated gene delivery system.

\section{Effect of co-cultivation period}

Duration of co-cultivation also an important factor in Agrobacterium- mediated plant genetic transformation. Two co-cultivation periods had highly significant effects in all the parameters studied (Table 2). The longer co-cultivation period ( $48 \mathrm{hrs}$ ) showed better performance than shorter one. The higher number and percentage of callus (12.45 and $51.87 \%$, respectively) were survived when they were kept in co-cultivation medium for two days (48 hrs). Rajagopalan and Perl-Treves (2005) [15] observed the highest survival rate $(72 \%)$ in cotylendonary explants of cucumber when those were co-cultivated for $24 \mathrm{hrs}$. But survival rate declined $(69 \%)$ with increase of co-cultivation period upto $48 \mathrm{hrs}$. They also observed the lowest survival rate (41\%) in contrast of the highest co-cultivation period (120 hrs). In present investigation there was scope to see the effect of survival rate as well as GUS response of variety Shital with more co-cultivation time considered in present investigation. Nishibayashi (1996) [12] successfully obtained transgenic cucumber plants after co-cultivated the calli for 5 days. The highest percentage $(48.36 \%)$ GUS +ve calli were obtained when co-cultivation time was 48 hrs. Rajagopalan and Perl-Treves (2005) [15] obtained the highest GUS foci (88 \%) from co-cultivation period of $120 \mathrm{hrs}$. Fang and Grumet (1990) [7] reported that three day co-cultivation period was the best for successful transformation in muskmelon. In an investigation of Agrobacterium - mediated transformation of potato Begam (2007) [4] observed that GUS expression increased with the increase of co-cultivation period. She reported that calli co-cultivated for 5 days gave higher $(58.53 \%)$ response to the GUS assay. Both the present and Begam's investigation were conducted in the same laboratory. From the above findings it was revealed that survival percentage of callus influenced by co-cultivation period.

From last two decades, A. tumefacines mediated plant genetic transformation has become well established in numerous laboratories and at present the most preferred method for cucumber transformation. The advantages of this method includes high transformation ability, minimal rearrangement of the transgene and a relatively high percentage of the transgenic plants that harbour a single copy of the transgene (Roy et al. 2000) [16]. The future aim of cucumber breeding may be use this transformation technique to develop value-added transgenic cucumber varieties by transforming single or many transgenes into commercially important cucumber varieties of Bangladesh or any part of the world. Figure 1 showed transformed and non-transformed leaf calli in eppendorf tubes. Figure 2 and 3 showed blue patches that indicated GUS activity and 
confirming GUS expression in transgenic leaf and nodal callus, respectively.

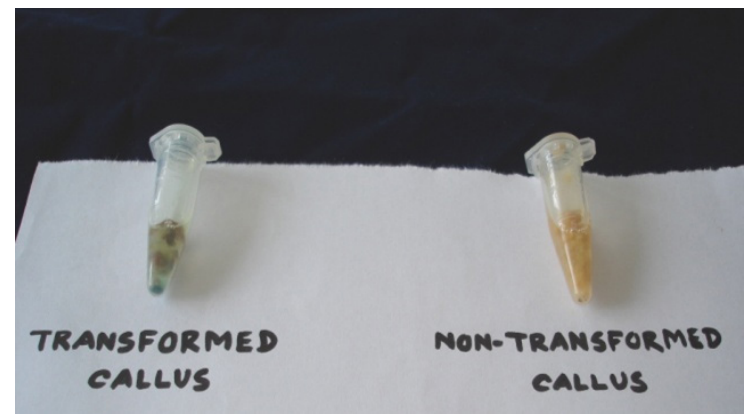

Figure 1. Successfully transformed (GUS +ve) (left) and non-transformed leaf calli (GUS -ve) (right)

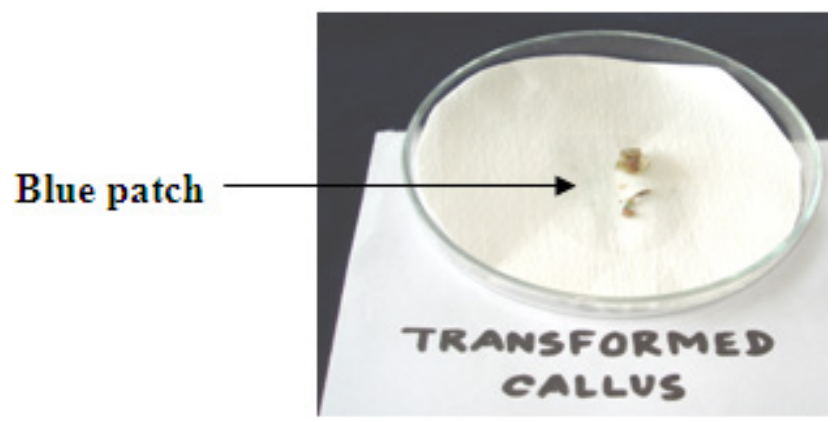

Figure 2. Transgenic leaf callus showing GUS +ve response

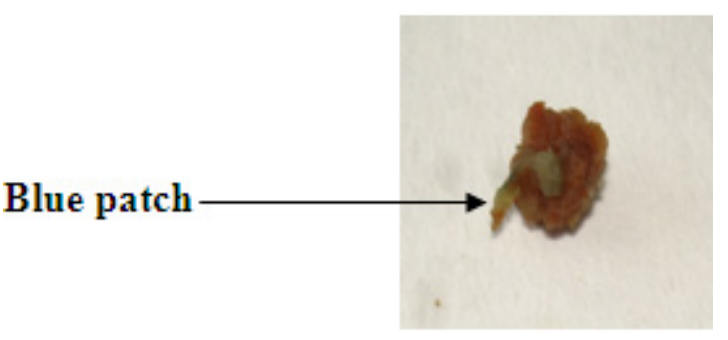

Figure 3. Transgenic nodal callus showing GUS +ve response

\section{Conclusions}

An efficient protocol for genetic transformation in cucumber was developed which showed transfer of CIPK sense gene in variety Shital and integration of two marker genes (GUS and npt II). The highest and the lowest GUS positive transgenic calli were obtained from leaf and internodal explants, respectively. Transformation ability was increased with increase of inoculation time (5 mins.). Duration of co-cultivation also an important factor in Agrobacterium mediated plant genetic transformation. The higher co-cultivation period (48 hrs.) showed better performance than lower one. For the development of abiotic stress tollerant cucumber varieties in Bangladesh this transformation protocol could be utilized successfully. Further transgenecity confirmation test like PCR, southern blotting, sequencing etc. to be needed to confirm transformation of putative transformed callus.

\section{Acknowledgements}

I am grateful to Bangladesh Agricultural Research institute (BARI) and the ministry of Science and technology of the Government of Bangladesh for providing financial supports during the study.

\section{REFERENCES}

[1] BBS. Statistical pocket book of Bangladesh. Bangladesh Bureau of statistics, Ministry of Planning, Government of the People's Republic of Bangladesh, Dhaka, Bangladesh. 209, 2008.

[2] BBS. Yearbook of Agricultural Statistics of Bangladesh. Bangladesh Bureau of statistics, Ministry of Planning, Government of the People's Republic of Bangladesh, Dhaka, Bangladesh. 34, 97, November, 2005.

[3] BBS. Monthly statistical bulletin-Bangladesh. Bangladesh Bureau of statistics, Ministry of Planning, Government of the People's Republic of Bangladesh, Dhaka, Bangladesh, 55, June, 2006.

[4] S.N. Begam. Agrobacterium-mediated transformation of potato for abiotic stress tolerance. MS thesis. Dept. of Biotechnology. Bangladesh Agricultural University, Mymensingh, 17-50, 2007.

[5] M.Z.F.A Begum. Agrobacterium-mediated genetic transformation in potato for abiotic stress tolerance. MS thesis. Dept. of Biotechnology. Bangladesh Agricultural University, Mymensingh, 26-70, 2005.

[6] H.S. Chawla. Introduction to Plant Biotechnology. Oxford \& IBH publishing Co. Pvt. Ltd., 66 Janapath, New Delhi 110001, India, 40-42, 2002.

[7] G. Fang and R. Grumet. Agrobacterium tumefaciens mediated transformation and regeneration of muskmelon plants. Plant Cell Reports, 9, 160-164, 1990.

[8] R. C. Gardner. Gene transfer into tropical and subtropical crops. Scientia Hort., 55, 65-82, 1993.

[9] R.A. Jefferson, T.A. Kavanagh and M.W. Bevan. GUS Fusion: $\beta$ - glucuronidase as a sensitive and versatile gene fusion marker in higher plants. EMBO J., 6, 3901-3907, 1986.

[10] S. Mahajan and N. Tuteja. Direct submission J. plant molecular Biol. I. C. G. E. B., New Delhi 110067, India, 2005.

[11] T. Murashige and F. Skoog. A revised medium for rapid growth and bioassays with tobacco tissue cultures. Physiol. Plant, 15, 473-497, 1962.

[12] S. Nishibayashi, H. Kaneko and T. Hayakawa. Transformation of cucumber (Cucumis sativus L.) plants using Agrobacterium tumefaciens and regeneration from hypocotyl explants. Plant Cell Reports, 15, 809-814, 1996.

[13] I. L. Nonnecki. Vegetable Production.. An AVI book, Van Nostrand Reinhold, 115 Fifth Avenue, New York 10003, USA, 509-526, 1989.

[14] L.C. Peirce. Vegetables: characteristics, production and 
marketing. John Wiley and Sons, USA, 357-366, 1987.

[15] P. A. Rajagopalan and R. Perl-Treves. Improved cucumber transformation by a modified explant dissection and selection protocol. Hort. Science, 40 (2), 431-435, 2005.

[16] M. Roy, R.K. Jain, J. S. Rohila and R. Wu. Production of agronomically superior transgenic rice plants using
Agrobacterium transformation methods: Present status and future perspectives. Current Science, Vol. 79, No. 7, 954-959, 2000 .

[17] W.B. Wang and A. Altman. Plant responses to drought, salinity and extreme temperatures: towards genetic engineering for stress tolerance. Intl. J. Plant. Biol., 218, 1-14, 2003. 